\title{
ЗМІНИ ВМІСТУ МАКРОЕЛЕМЕНТІВ У КІСТКАХ СКРОНЕВО-НИЖНЬОЩЕЛЕПНОГО СУГЛОБА ПРИ ЙОГО ДІАБЕТИЧНОМУ УШКОДЖЕННІ
}

Вступ. Ушкодження суглобів у хворих на цукровий діабет є досить частим ускладненням. Особливості макроелементного складу скроневої кістки і нижньої щелепи та структурні зміни скронево-нижньощелепного суглоба при цукровому діабеті вивчено недостатньо.

Мета дослідження - вивчити особливості макроелементного складу скроневої кістки та нижньої щелепи при діабетичній артропатії скронево-нижньощелепного суглоба.

Методи дослідження. За допомогою атомно-абсорбційного спектрального аналізу досліджено вміст макроелементів (кальцію, фросфрору, магнію, натрію), відношення вмісту кальцію до вмісту фросфрору в скроневій кістці та нижній щелепі 45 лабораторних статевозрілих білих щурів-самців, яких поділили на З групи. До 1-ї групи входили 15 інтактних практично здорових тварин, до 2-ї- 15 щурів з місячною діабетичною артропатією скронево-нижньощелепного суглоба, до 3-ї - 15 тварин із двомісячною вказаною патологією. Із суглоба, скроневої кістки та нижньої щелепи виготовляли також гістологічні мікропрепарати, на яких визначали відносні об'єми ушкоджених хондроцитів, синовіоцитів, у кістковій тканині - відносні об'єми остеобластів та остеокластів. Проводили кореляційний аналіз між досліджуваними морфометричними показниками та вмістом макроелементів. Цукровий діабет моделювали шляхом одноразового внутрішньочеревного введення стрептозотоцину фрірми "Sigma" в дозі 50 мг/кг. Кількісні показники обробляли статистично.

Результати й обговорення. При діабетичній артропатії скронево-нижньощелепного суглоба диспропорційно та нерівномірно зменшується вміст фоосфору, кальцію, магнію, вміст натрію збільшується у кістковій тканині скроневої кістки і нижньої щелепи. Встановлено, що у скроневій кістці вміст кальцію при місячній діабетичній артропатії скронево-нижньощелепного суглоба зменшився на 4,8 \%, а в нижній щелепі - на 8,8 \%, при двомісячній артропатії досліджувані показники змінилися, відповідно, на 8,6 та 11,6 \% (р<0,001), фроссрору - на 10,0, 15,4, 14,7 і 18,9 \% відповідно. Вміст магнію у скроневій кістиі при місячній діабетичній артропатії зменшився на 6,1 \%, а в нижній щелепі - на 11,4 \%, при двомісячному перебізі змодельованої патології - на 15,8 та 21,8 \% відповідно (p<0,001). Вміст натрію у скроневій кістці та нижній щелепі за досліджуваних експериментальних умов збільшувався. При змодельованій гіперглікемії суттєво змінювалося відношення Са/P, що залежало від тривалості діабетичної артропатії та домінувало в нижній щелепі.

Висновки. Діабетична артропатія скронево-нижньощелепного суглоба призводить до нерівномірного, диспропорційного зменшення вмісту кальцію, фосфрору, магнію і збільшення вмісту натрію у скроневій кістці та нижній щелепі. Найвиразніший дисбаланс між вмістом досліджуваних макроелементів виявлено при двомісячній діабетичній артропатії скронево-нижньощелепного суглоба та в нижній щелепі. Дисбаланс макроелементів у скроневій кістці й нижній щелепі при експериментальному цукровому діабеті впливає на порушення процесів хондрогенезу, мінералізації та остеогенезу.

КЛЮЧОВІ СЛОВА: скронево-нижньощелепний суглоб; діабетична артропатія; макроелементи; скронева кістка; нижня щелепа.

ВСТУП. Цукровий діабет - поширене захворювання, яке має тенденцію до зростання, нерідко призводить до інвалідності та смертності хворих і $є$ важливою медичною та соціальною проблемою. Ушкодження суглобів у пацієнтів 3 гіперглікемією $є$ досить частим ускладненням. За даними багатьох дослідників, більш ніж у 50 \% хворих на цукровий діабет 1 та 2 типів діагностують артропатію, тобто діабетасоційований С М. С. Гнатюк, Л. В. Рубас, Л. В. Татарчук, Р. І. Цицюра, 2021. остеоартрит [1, 2]. При вказаній патології через енергетичний дефріцит порушується вуглеводний, білковий, мінеральний обмін, виникають гормональні розлади, ангіо- і нейропатії, зміни реології та гемодинаміки в гемомікроциркуляторному руслі, що ускладнюються резорбцією кісткової тканини внаслідок дисбалансу остеобластної і остеокластної активності [1, 2]. У результаті високої глюкозотоксичності відбуваються накопичення кінцевих продуктів гліколізу, 
активація оксидативного стресу, а також розвиток низькорівневого запалення на організменному рівні. Ці фрактори зумовлюють аномальне ремоделювання хрящової, синовіальної, кісткової тканин та біохімічні зміни, що ускладнюються діабетасоційованою артропатією [1, 3, 4].

Скронево-нижньощелепний суглоб, який $€$ найактивнішим суглобом людського організму, утворюють нижньощелепна ямка скроневої кістки, головка нижньої щелепи та внутрішньосуглобовий диск. Варто зазначити, що макроелементний склад скроневої кістки та нижньої щелепи при діабетичній артропатії скроневонижньощелепного суглоба залишається маловивченим. Водночас слід зауважити, що дослідження вмісту макроелементів у кістковій тканині $€$ важливим для пояснення фрізіологічного та репаративного остеогенезу [3].

Мета дослідження - вивчити особливості макроелементного складу скроневої кістки та нижньої щелепи при діабетичній артропатії скронево-нижньощелепного суглоба.

МЕТОДИ ДОСЛІДЖЕННЯ. За ДОПОМогою атомно-абсорбційного спектрального аналізу [5] досліджено вміст макроелементів у скроневій кістці та нижній щелепі 45 лабораторних статевозрілих білих щурів-самців, яких поділили на 3 групи. До 1-ї групи входили 15 інтактних практично здорових тварин, до 2-ї - 15 щурів з місячною діабетичною артропатією скронево-нижньощелепного суглоба, до 3-ї - 15 тварин із двомісячною вказаною патологією. Цукровий діабет моделювали шляхом одноразового внутрішньочеревного введення стрептозотоцину фрірми "Sigma" в дозі 50 мг/кг. Евтаназію тварин здійснювали через 1 і 2 місяці шляхом кровопускання за умов тіопенталового наркозу. Скроневу кістку та нижню щелепу очищували від м'яких тканин, і за допомогою атомно-абсорбційного спектрального аналізу визначали у вказаних кістках вміст кальцію, фросфору, магнію, натрію, відношення вмісту кальцію до вмісту фросорору. Зі скронево-нижньощелепного суглоба, скроневої кістки і нижньої щелепи виготовляли також гістологічні мікропрепарати [6], на яких морфометрично визначали відносні об'єми ушкоджених синовіоцитів (ВОУС), зрілих хондроцитів (ВОУЗХ), відносні об'єми остеокластів (ВООК) та остеобластів (ВООБ) [7]. Морфометрію структур скронево-нижньощелепного суглоба, скроневої кістки та нижньої щелепи виконували, використовуючи світловий мікроскоп "Olimpus BX-23" із цифровою відеокамерою і пакетом прикладних програм "Відео-тест 5,0" та "Відео-розмір 5,0". Проводили кореляційний аналіз між вмістом макроелементів та досліджуваними гістостерео- метричними показниками суглоба і кісток із визначенням коефіцієнта (r) кореляції. Силу зв'язку оцінювали за 4 ступенями: сильний $(r=0,7-$ $0,9)$, значний $(r=0,5-0,7)$, помірний $(r=0,3-0,5)$, слабкий $(r<0,3)[7]$.

Отримані кількісні показники обробляли статистично. Обробку отриманих результатів виконано у відділі системних статистичних досліджень Тернопільського національного медичного університету імені І. Я. Горбачевського MO3 України у програмному пакеті STATISTICA (Stat. Soft. Inc, США). Різницю між порівнюваними показниками визначали за критеріями Стьюдента і Манна - Уїтні [8].

Варто вказати, що експериментальні дослідження та евтаназію піддослідних тварин виконували з дотриманням Загальних етичних принципів експериментів на тваринах, ухвалених на Першому національному конгресі з біоетики (Київ, 2001), і відповідно до Європейської конвенції про захист хребетних тварин, що використовуються для дослідних та інших наукових цілей [9].

РЕЗУЛЬТАТИ Й ОБГОВОРЕННЯ. ОТрИмані в результаті проведеного дослідження дані наведено в таблицях 1, 2. Під час усестороннього аналізу встановлено, що вміст досліджуваних макроелементів у неушкоджених скроневій кістці та нижній щелепі й кількісні морфологічні показники їх структур були однаковими. При експериментальній гіперглікемії в усіх спостереженнях 2-ї і 3-ї груп виявлено артропатію скронево-нижньощелепного суглоба, яка підтверджувалася гістологічно (дегенеративні, дистрофрічні й некробіотичні зміни у хрящовій тканині) та морфометрично (збільшення відносних об'ємів ушкоджених синовіоцитів і хондроцитів).

Встановлено також, що вже при місячній діабетичній артропатії вміст макроелементів змінювався. Так, у скроневій кістці вміст кальцію при місячній артропатії статистично достовірно ( $<<0,001)$ зменшився на 4,8 \%, а в нижній щелепі - на 8,8 \% (р<0001), при двомісячній артропатії досліджувані показники змінилися, відповідно, на 8,6 та $11,6 \%(p<0,001)$.

Вміст фросорору в досліджуваних кістках також змінювався. При місячній змодельованій патології вказаний макроелемент у скроневій кістці зменшився на 10,0 \% (p<0,001), а в нижній щелепі-на 14,7 \%, при двомісячному ушкодженні скронево-нижньощелепного суглоба за умов експериментального цукрового діабету досліджувані показники знизились, відповідно, на 15,4 та 18,9 \% (р<0,001). Відомо, що кальцій і фросфрор $€$ основними макроелементами кісткової тканини, які становлять основу її твердої речовини 
Таблиця 1 - Вміст макроелементів у кістках скронево-нижньощелепного суглоба експериментальних тварин (M $\pm \mathrm{m})$

\begin{tabular}{|c|c|c|c|}
\hline \multirow{2}{*}{ Показник } & \multicolumn{3}{|c|}{ Група спостереження } \\
\hline & 1-ша & 2-га & 3-тя \\
\hline \multicolumn{4}{|c|}{ Скронева кістка } \\
\hline $\mathrm{Ca}, \mathrm{Mr} / \mathrm{r}$ & $107,70 \pm 1,20$ & $102,50 \pm 0,93^{\star *}$ & $98,40 \pm 0,84^{\star \star}$ \\
\hline $\mathrm{P}, \mathrm{Mr} / \Gamma$ & $81,80 \pm 0,72$ & $73,60 \pm 0,66^{\star \star \star}$ & $69,20 \pm 0,63^{\star \star \star}$ \\
\hline $\mathrm{Ca} / \mathrm{P}$ & $1,31 \pm 0,02$ & $1,39 \pm 0,02^{*}$ & $1,42 \pm 0,02^{\star \star}$ \\
\hline $\mathrm{Mg}, \mathrm{Mr} / \Gamma$ & $1,90 \pm 0,02$ & $1,76 \pm 0,02^{\star \star \star}$ & $1,60 \pm 0,02^{\star \star \star}$ \\
\hline $\mathrm{Na}, \mathrm{Mr} / \Gamma$ & $6,10 \pm 0,05$ & $6,38 \pm 0,04^{\star \star}$ & $6,70 \pm 0,06^{\star \star \star}$ \\
\hline \multicolumn{4}{|c|}{ Нижня щелепа } \\
\hline Са, мг/г & $108,20 \pm 1,20$ & $98,70 \pm 0,93^{\star \star \star}$ & $95,60 \pm 0,87^{\star \star \star}$ \\
\hline $\mathrm{P}, \mathrm{Mr} / \mathrm{\Gamma}$ & $82,30 \pm 0,72$ & $70,20 \pm 0,63^{\star \star \star}$ & $66,70 \pm 0,63^{\star \star \star}$ \\
\hline $\mathrm{Ca} / \mathrm{P}$ & $1,31 \pm 0,02$ & $1,40 \pm 0,02^{\star \star}$ & $1,43 \pm 0,02^{\star \star}$ \\
\hline $\mathrm{Mg}, \mathrm{Mг} / \mathrm{\Gamma}$ & $1,92 \pm 0,02$ & $1,70 \pm 0,02^{\star \star \star}$ & $1,50 \pm 0,02^{\star \star \star}$ \\
\hline $\mathrm{Na}, \mathrm{мг} / \Gamma$ & $6,12 \pm 0,04$ & $6,45 \pm 0,05^{\star \star \star}$ & $6,90 \pm 0,05^{\star \star \star}$ \\
\hline
\end{tabular}

Примітка. * $-p<0,05,{ }^{* *}-p<0,01$, *** $-p<0,001$ порівняно 3 1-ю групою.

$[10,11]$. Зміни вмісту вказаних базових хімічних середників призводять до порушень мінералізації кістки та остеогенезу [3, 10, 11].

Отримані та проаналізовані дані свідчать про те, що вміст кальцію і фоссрору в досліджуваних кістках зменшувався нерівномірно, диспропорційно, що адекватно відображало відношення між вмістом кальцію та фоссрору. Так, при місячній діабетичній артропатії вказане відношення у скроневій кістці статистично достовірно збільшилося на $3,8 \%(p<0,05)$, а в нижній щелепі-на $6,8 \%(p<0,01)$, при двомісячній артропатії наведені показники змінилися, відповідно, на 8,3 та 9,1 \% $(\mathrm{p}<0,01)$ порівняно 3 аналогічним контролем.

Варто зазначити, що магній - один із поширених у людському організмі макроелементів. Відомо, що його третина локалізована в кістках і виконує фрункцію депо [10]. При місячній діабетичній артропатії скронево-нижньощелепного суглоба вміст магнію у скроневій кістці статистично достовірно $(p<0,01)$ зменшився на $7,4 \%$, а при двомісячній вказаній патології - на $15,8 \%$ ( $p<0,001)$. Зниження кількості магнію призводить до гіпокальціємії, сповільнення росту кісток, прискорення процесів резорбції, зменшення маси кісток, остеопорозу [10, 11]. Вміст магнію в нижній щелепі при змодельованій патології зменшився, відповідно, на 11,4 та $21,8 \%(p<0,001)$.

Вміст у досліджуваних кістках натрію при змодельованій експериментальній гіперглікемії зростав. Так, при місячній діабетичній артропатії скронево-нижньощелепного суглоба вміст вказаного хімічного середника у скроневій кістці збільшився $3(6,10 \pm 0,05)$ до $(6,38 \pm 0,04) \mathrm{mr} / r$, тобто на $4,5 \%(p<0,01)$. За умов цього експерименту вміст натрію в нижній щелепі зріс на 5,4 \% $(p<0,01)$. При двомісячній діабетичній артропатії скронево-нижньощелепного суглоба вміст даного макроелемента у скроневій кістці з вираженою статистично достовірною різницею $(p<0,001)$ підвищився на 5,8 \%, а в нижній щелепі - на $12,7 \%(p<0,001)$.

Гістологічно відмічали дегенеративні процеси у хрящах нижньощелепної ямки скроневої кістки та головки нижньої щелепи. У досліджуваних кістках (скронева кістка, нижня щелепа) спостерігали порожнини резорбції, мозаїчно забарвлені ділянки з вираженим деструктивним процесом. Мали місце зменшення кількості остеобластів, зростання числа остеокластів, а також зони патологічного кісткоутворення, що характеризувалися збільшенням кількості ати-

Таблиця 2 - Морфометрична характеристика структур скронево-нижньощелепного суглоба в експериментальних тварин

\begin{tabular}{||l|c|c|c|}
\hline \multirow{2}{*}{\multicolumn{1}{|c|}{ Показник }} & \multicolumn{3}{|c|}{ Група спостереження } \\
\cline { 2 - 4 } & 1 -ша & 2 -га & 3-тя \\
\hline ВОУЗХ, \% & $2,10 \pm 0,02$ & $13,65 \pm 0,15^{\star \star \star}$ & $15,20 \pm 0,16^{\star \star \star}$ \\
\hline ВОУС, \% & $2,15 \pm 0,02$ & $16,10 \pm 0,15^{\star \star \star}$ & $21,50 \pm 0,18^{\star \star \star}$ \\
\hline ВООБСк, \% & $28,20 \pm 0,18$ & $21,40 \pm 0,16^{\star \star \star}$ & $15,60 \pm 0,14^{\star \star \star}$ \\
\hline ВООКСк, \% & $2,09 \pm 0,02$ & $5,64 \pm 0,03^{\star \star \star}$ & $12,50 \pm 0,06^{\star \star \star}$ \\
\hline ВООБНщ, \% & $28,22 \pm 0,18$ & $20,60 \pm 0,15^{\star \star \star}$ & $13,40 \pm 0,15^{\star \star \star}$ \\
\hline ВООКНщ, \% & $2,10 \pm 0,02$ & $6,70 \pm 0,04^{\star \star \star}$ & $14,30 \pm 0,12^{\star \star \star}$ \\
\hline
\end{tabular}

Примітки:

1. *** - $<<0,001$ порівняно 3 1-ю групою.

2. Ск - скронева кістка, Нщ - нижня щелепа. 
пових кісткових балок з порушеною гістологічною структурою, що визначалося за розростанням клітинно-волокнистої тканини в міжбалкових просторах. Виявлені морфологічні зміни домінували в нижній щелепі. Наведене, а також виразніший дисбаланс між вмістом макроелементів у вказаній кістці при змодельованій артропатії можна пояснити більшим навантаженням, яке припадає на неушкоджену нижню щелепу, а також патологічними станами.

Як свідчать результати проведених досліджень, діабетична артропатія скронево-нижньощелепного суглоба суттєво змінює вміст макроелементів у скроневій кістці та нижній щелепі. Варто зазначити, що вміст основних макроелементів (кальцію і фоосфору) в досліджуваних кістках знижується нерівномірно та диспропорційно, суттєво порушуючи баланс між ними, що адекватно підтверджується змінами відношень між вмістом вказаних хімічних речовин. Найвиразніше вміст досліджуваних макроелементів у скроневій кістці та нижній щелепі змінився при двомісячній діабетичній артропатії скроневонижньощелепного суглоба. Необхідно зазначити, що за умов експерименту вміст натрію в скроневій кістці та нижній щелепі зростав, виражено порушуючи дисбаланс між кістковими макроелементами. Виявлені диспропорційні зміни макроелементів у скроневій кістці та нижній щелепі при експериментальному цукровому діабет свідчать про неоднорідність і порушення механізмів перебігу процесів остеогенезу та мінералізації в цих кістках [3, 10, 11].

Найбільш виражені кореляційні зв'язки виявлено у 3-й групі спостережень між досліджуваними макроелементами і морфометричними

\section{СПИСОК ЛІТЕРАТУРИ}

1. Орленко В. Л. Гормональні характеристики діабет-асоційованих остеоартритів // Вісн. проблем біології та медицини. - 2020. - Вип. 2 (159). - С. 138143.

2. Кризина О. В. Трофрічні порушення тканин нижніх кінцівок при цукровому діабеті 2 типу // Клініч. ендокринологія та ендокринна хірургія. - 2018. № 1 (6). - С. 15-24.

3. Лукьянцева Г. В. Особенности химического состава костей белых крыс после двухмесячного употребления натрия бензола и возможности его коррекции // Укр. морфол. альм. - 2014. - 12, № 4. C. 61-66.

4. Berenbaum F. Diabetes induced osteoarthritis from a new paradigm to a new phenotype / F. Berenbaum. Ann. Rheum. Dis. - 2011. - 70 (8). - P. 1354-1356. параметрами досліджуваних структур. Під час проведення кореляційного аналізу встановлено наявність значних негативних кореляційних зв'язків між відносними об'ємами остеокластів та вмістом у кістках кальцію і фросфору $(r=-0,65 \pm 0,03)$. Більшої сили позитивні зв'язки відзначено між вказаним гістостереометричним параметром та співвідношенням $\mathrm{Ca} / \mathrm{P}$ $(r=+0,81 \pm 0,04)$. Між відносними об'ємами ушкоджених синовіоцитів і хондроцитів у 3-й групі спостережень та вмістом натрію в досліджуваних кістках коефіцієнт кореляції коливався в межах від 0,52 до 0,64 (значні зв'язки). Виявлені кореляційні зв'язки свідчили про те, що дисбаланс між вмістом основних макроелементів у кістковій тканині суттєво впливає на хондрогенез, мінералізацію та остеогенез.

ВИСНОВКИ. Діабетична артропатія скронево-нижньощелепного суглоба призводить до нерівномірного, диспропорційного зменшення вмісту кальцію, фросфору, магнію і збільшення вмісту натрію у скроневій кістці та нижній щелепі. Найвиразніший дисбаланс між вмістом досліджуваних макроелементів виявлено при двомісячній діабетичній артропатії скронево-нижньощелепного суглоба та в нижній щелепі. Дисбаланс макроелементів у скроневій кістці й нижній щелепі при експериментальному цукровому діабеті впливає на порушення процесів хондрогенезу, мінералізації та остеогенезу.

Перспективи подальших досліджень. Всестороннє вивчення вмісту макроелементів у кістковій тканині при діабетичних артропатіях дозволить при цьому суттєво покращити діагностику, корекцію та профрілактику уражень кісток.

5. Брицке Э. М. Атомно-абсорбционный спектральный анализ / Э. М. Брицке. - М. : Химия, 1982. 244 c.

6. Горальський Л. П. Основи гістологічної техніки і морфрофункціональні методи дослідження в нормі і при патології / Л. П. Горальський, В.П.Хомич, О. І. Кононський. - Житомир : Полісся, 2011. - 288 с.

7. Автандилов Г. Г. Основы количественной патологической анатомии / Г. Г. Автандилов. - М. : Медицина, 2002. - 240 с.

8. Гжибовский А. И. Сравнение количественных данных двух парных выборок с использованием программного обеспечения Statistika i SPSS: параметрические и непараметрические критерии / А. И. Гжибовский, О. И. Иванов, М. А. Горбатова // Наука и здравоохранение. - 2016. - № 3. - С. 5-25. 
9. Резніков О. Г. Загальні етичні принципи експериментів на тваринах / О. Г. Резніков // Ендокринологія. - 2003. - № 8 (1). - С. 142-145.

10. Мікроелементний склад довгих та мішаних кісток скелета в нормі / Є. В. Гусак, М.В.Погорелов,

\section{REFERENCES}

1. Orlenko, L. (2020). Hormonalni kharakterystyky diabet-asotsiiovanykh osteoartrytiv [Hormonal characteristics of diabetes-associated osteoarthritis]. Visnyk problem biolohii ta medytsyny - Bulletin of Problems of Biology and Medicine, 2 (159), 138-143 [in Ukrainian].

2. Kryzyna, O.V. (2018). Trofichni porushennia tkanyn nyzhnikh kintsivok pry tsukrovomu diabeti 2 typu [Trophic disorders of the tissues of the lower extremities in type 2 diabetes]. Klinichna endokrynolohiia ta endokrynna khirurhiia - Clinical Endocrinology and Endocrine Surgery, 1 (6), 15-24 [in Ukrainian].

3. Lukyantseva, G.V. (2014). Osobennosti khimicheskogo sostava kostey belykh krys posle dvukhmesyachnogo upotrebleniya natriya benzola i vozmozhnosti yego korrektsii [Features of the chemical composition of the bones of white rats after two months of use of benzene sodium and the possibility of its correction]. Ukrainskyi morfolohichnyi almanakh - Ukrainian Morphological Almanac, 12 (4), 61-66 [in Ukrainian].

4. Berenbaum, F. (2011). Diabetes induced osteoarthritis from a new paradigm to a new phenotype. Ann. Rheum. Dis., 70 (8), 1354-356.

5. Britske, E.M. (1982). Atomno-absorbtsionnyy spektralnyy analiz [Atomic absorption spectral analysis]. Moscow: Khimiya [in Russian].

6. Horalskyy, L.P., Khomych, V.P., \& Konopskyy, O.I. (2011). Osnovy histolohichnoi tekhniky imorfofunktsionalni metody doslidzhennia vnormi i pry patolohii [Fundamentals of histological technique and morphofunctional research methods in normal and in pathology]. Zhytomyr: Polissia [in Ukrainian].
Г. Ф. Ткач, С. М. Данильченко // Укр. морфол. альм. 2010. - 8, № 4. - С. 51-55.

11. Зміни хімічного складу кісток щурів під впливом жовтого барвника тартразину / Г. В. Лук'янцева В. А. Пастухова, О. Г. Ковальчук, У. М. Дутчак // Світ медицини та біології. - 2019. - № 4 (70). - С. 203-208.
7. Avtandylov, G.G. (2002). Osnovy kolichestvennoy patologicheskoy anatomii [Basis of quantative pathological anatomy]. Moscow: Meditsyna [in Russian].

8. Gzhibovskiy, A.I., Ivanov, O.I., \& Gorbatova, M.A. (2016). Sravneniye kolichestvennykh dannykh dvukh parnykh vyborok $s$ ispolzovaniyem programmnogo obespecheniya Statistika i SPSS: parametricheskiye i neparametricheskiye kriterii [Comparison of quantitative data of two paired samples using Statistika i SPSS software: parametric and nonparametric criteria]. Nauka i zdravookhraneniye - Science and Healthcare, 3, 5-25 [in Ukrainian].

9. Reznikov, O.H. (2003). Zahalni etychni pryntsypy eksperymentiv na tvarynakh [General ethical principles of animal experiments]. Endokrynolohiia-Endocrinology, 8 (1), 142-145 [in Ukrainian].

10. Husak, Ye.V., Pohorelov, M.V., Tkach, H.F., \& Danylchenko, S.M. (2010). Mikroelementnyi sklad dovhykh ta mishanykh kistok skeleta v normi [Microelement composition of long and mixed skeletal bones in norm]. Ukrainskyi morfolohichnyi almanakh - Ukrainian Morphological Almanac, 8 (4), 51-55 [in Ukrainian].

11. Lukyantseva, H.V., Pastukhova, V.A., Kovalchuk, O.H., \& Dutchak, U.M. (2019). Zminy khimichnoho skladu kistok shchuriv pid vplyvom zhovtoho barvnyka tartrazynu [Changes in the chemical composition of rat bones under the influence of the yellow dye tartrazine]. Svit medytsyny ta biolohii - The World of Medicine and Biology, 4 (70), 203-208 [in Ukrainian].

\section{CHANGES IN THE CONTENT OF MACROELEMENTS IN THE BONE OF THE TEMPOROMANDIBULAR JOINT AT ITS DIABETIC DAMAGE}

\section{Summary}

Introduction. Joint damage in patients with diabetes is a fairly common complication. Peculiarities of the macroelements composition of the temporal bone and mandible and structural changes of the temporomandibular joint in diabetes have been insufficiently studied.

The aim of the study - to learn the features of the macroelements composition of the temporal bone and mandible at diabetic arthropathy of the temporomandibular joint. 
Research Methods. Atomic absorption spectral analysis examined the content of macroelements (calcium, phosphorus, magnesium, sodium), the ratio of calcium to phosphorus in the temporal bone of the mandible of 45 laboratory adult white male rats, which were divided into 3 groups. Group 1 consisted of 15 intact almost healthy animals, group $2-15$ rats with monthly diabetic arthropathy of the temporomandibular joint, group $3-15$ animals with two-month specified pathology. Histological micronutrients were also made of the joint, temporal bone and mandible, on which the relative volumes of damaged chondrocytes and synoviocytes were determined, and the relative volumes of osteoblasts and osteoclasts in bone tissue. A correlation analysis was performed between the studied morphometric parameters and the content of macroelements. Diabetes mellitus was simulated by a single intraperitoneal injection of streptozotocin by Sigma at a dose of $50 \mathrm{mg} / \mathrm{kg}$. Quantitative indicators were processed statistically.

Results and Discussion. It was established that in diabetic arthropathy of the temporomandibular joint the content of phosphorus, calcium and magnesium decreases disproportionately and unevenly, sodium content increases in the bone tissue of the temporal bone and mandible. It was found that the calcium content in the temporal bone in monthly diabetic arthropathy decreased by $4.8 \%$, and in the mandible - by $8.8 \%$, in two-month arthropathy, the studied indicators changed by $8.6 \%$ and $11.6 \%$, respectively $(p<0.001$, phosphorus - by $10 \%, 15.4 \%, 14.7 \%$ and $18.9 \%$, respectively. The magnesium content in monthly diabetic arthropathy of the temporomandibular joint in the temporal bone decreased by $6.1 \%$. in the mandible - by $11.4 \%$, with a two-month course of simulated pathology - by $15.8 \%$ and $21.8 \%$, respectively $(p<0.001)$. The sodium content in the temporal bone and mandible under the studied experimental conditions increased. In simulated hyperglycemia, the Ca/P ratio varied significantly and depended on the duration of diabetic arthropathy and dominated in mandible.

Conclusions. Diabetic arthropathy of the temporomandibular joint leads to an uneven, disproportionate decrease in calcium, phosphorus, magnesium and an increase in sodium in the temporal bone and mandible. The most pronounced imbalance between the content of the studied macroelements was found in two-month diabetic arthropathy of the temporomandibular joint and in the mandible. Macroelements imbalance in the temporal bone and mandible in experimental diabetes mellitus affects the disruption of chondrogenesis, mineralization and osteogenesis.

KEY WORDS: temporomandibular joint; diabetic arthropathy; macroelements; temporal bone; mandible.

Отримано 28.07.21

Адреса для листування: М. С. Гнатюк, Тернопільський національний медичний університет імені І. Я. Горбачевського мОз України, майдан Волі, 1, Тернопіль, 46001, Україна, e-mail: hnatjuk@tdmu.edu.ua. 